\title{
Upgrade Skill Komputer Perangkat Desa Pemakuan
}

\author{
Dwi Kartini ${ }^{*}$ dan Arfan Eko². \\ Prodi Ilmu Komputer, FMIPA Universitas Lambung Mangkurat \\ Jl. A. Yani, Km 36 , Banjarbaru, Kalimantan Selatan \\ 1*dwikartini@ulm.ac.id \\ Prodi Fisika, FMIPA Universitas Lambung Mangkurat \\ Jl. A. Yani, Km 36 , Banjarbaru, Kalimantan Selatan \\ 2 arfan.eko@gmail.com
}

Artikel diterima: 26-09-2019, direvisi: 11-10-2019, diterbitkan: 25-12-2019

\begin{abstract}
Abstrak
Kegiatan pengabdian dan kemitraan dengan masyarakat (PKM) ini memiliki tujuan memberikan motivasi, meningkatkan wawasan, ketrampilan penggunaan teknologi komputer dan informasi bagi perangkat desa Sungai Tabuk dalam meningkatkan pelayanan kepada masyarakat. Metode yang digunakan adalah ceramah dan praktek langsung. Hasil kegiatan menunjukkan terdapat peningkatan kemampuan dan ketrampilan menggunakan komputer sebesar $75 \%$ dan terdapat beberapa kegiatan desa yang menggunakan aplikasi komputer. Kendala yang muncul adalah terbatasnya sarana dan prasarana desa sehingga kegiatan belum berjalan maksimal.

Kata Kunci: Database desa, PKM, Sungai Tabuk.
\end{abstract}

\section{Abstract}

This community service and partnership (PKM) activity has the aim of providing motivation, increasing insight, skills in the use of computer and information technology for village officials in improving services to the community. The method used is lecture and direct practice. The results of the activities show there is an increase in the ability and skills of using a computer by $75 \%$ and there are several village activities that use computer applications. The obstacle that arises is the limited facilities and infrastructure of the village so that activities have not been running optimally.

Keywords: Village database, PKM, Sungai Tabuk.

\section{Pendahuluan}

Desa merupakan suatu wilayah kesatuan masyarakat hukum yang memiliki batas wilayah yang berwenang untuk mengatur dan mengurus urusan pemerintahan, kepentingan masyarakat setempat berdasarkan prakarsa masyarakat, hak asal usul, dan/atau hak tradisional yang diakui dan dihormati dalam sistem pemerintahan Negara Kesatuan Republik Indonesia (Anonymus 2014).

Perangkat desa memiliki peran dalam melakukan pengumpulan data warga di desa, pengolahan dan publikasi data dalam bentuk profil desa, serta melayani adminitrasi warga. Setelah data diperoleh data kemudian diolah melalui program aplikasi maupun secara manual. Saat ini 
telah banyak program atau aplikasi yang dapat digunakan dalam mengolah data dan menampilkan data berdasarkan kebutuhan informasi desa..

Perkembangan teknologi informasi yang sangat pesat memaksa manusia untuk mampu beradaptasi bekerja cepat, akurat dan efisien. Pengolahan data dan informasi diproses secara manual memiliki banyak kendala baik faktor eksternal maupun internal. Dewasa ini sistem informasi berbasis komputer kini mulai banyak digunakan oleh instansi pemerintahan maupun swasta untuk menggantikan pengolahan data yang manual menjadi informasi. Sistem berbasis komputer ini membuat pengguna lebih mudah dan cepat dalam pengolahan data menjadi informasi (Suprapto 2016).

Desa pemakuan adalah desa yang terletak di pinggiran aliran sungai Martapura. Selama ini, pekerjaan adminsitrasi banyak dilakukan oleh Pembakal atau Kepala Desa. Hal ini disebabkan oleh kemampuan komputer perangkat desa yang bertugas sebagai administrasi sangat terbatas.

Program Kemitraan Masyarakat (PKM) merupakan program pengabdian oleh dosen ULM. Melalui kegiatan PKM tim dosen dari prodi IImu komputer dan Fisika melakukan pelatihan untuk meningkatkan skill komputer perangkat desa Pemakuan, agar mampu melayani masyarakat dan mengarsipkan data menggunakan komputer.

\section{Metode}

Kegiatan dilaksanakan dalam bentuk pelatihan dan praktek langsung yang diikuti perangkat desa Pemakuan. Materi pelatihan di sesuaikan dengan kebutuhan dan aplikasi yang paling sering digunakan. Pengenalan terhadap web diskusi desa juga disampaikan. Pelatihan dilakukan selama 2.5 jam dalam sekali tatap muka.

Pelaksanan pelatihan dibantu oleh dua orang mahasiswa yang berasal dari program studi IImu Komputer FMIPA ULM. Mahasiwa bertugas sebagai asisten pemateri dalam pelatihan. Jumlah perangkat desa yang diikut dalam kegiatan pelatihan adalah 4-6 orang. Hal ini disesuaikan dengan tugas administrasi dari perangkat desa tersebut.

\section{Hasil dan Pembahasan}

Pemerintah desa merupakan unsur penyelenggara pemerintahan desa yang terdiri dari kepala desa dan perangkat desa sebagai unsur pembantu. Pemerintah desa sebagai suatu organisasi harus memperhatikan sumber daya manusia (SDM), karena SDM mempunyai peranan yang penting (Moeljanto 2009). Berdasarkan permasalahan yang dihadapi mitra, seperti yang diungkapkan di bagian pendahuluan. maka kegiatan PKM telah dilaksanakan sebagai alternatif solusi melalui pendekatan individual dan klasikal. Pendekatan klasikal dilaksanakan pada saat pemberian dan penyampaian materi mengenai penggunaan komputer. Sedangkan pendekatan individual dilakukan 
pada saat latihan dan tanya-jawab.

Materi yang disampaikan pada kegiatan PKM adalah pelatihan aplikasi perkantoran menggunakan software Microsoft Office 2013 untuk memudahkan di dalam mengelola data desa. Selain itu juga disampaikan beberapa web yang bisa dimanfaatkan untuk berdiskusi dan mencari solusi masalah pedesaan. Sebagian peserta pelatihan yang merupakan perangkat desa sudah mengenal software tersebut (khususnya Ms.Word dan Ms.Excel) untuk membuat administrasi surat menyurat, pengumpulan data jumlah penduduk dan laporan penggunaan anggaran desa yang diketik dalam lembar kerja excel tanpa mengetahui proses pengolahan fungsi yang ada dalam menyajikan informasi. Penggunaan komputer sejauh ini hanya sebatas dalam membuat laporan saja dengan mengetik hasil proses pengolahan data secara manual seperti jumlah warga yang masuk atapun warga yang keluar.

Pelatihan ini diikuti oleh lima orang perangkat desa dengan materi yang disampaikan berupa pengolahan kata dan data menggunakan Ms. Word, Ms. Excel dan Ms. Access penyajian presentasi Ms. Power point sebagai penunjang perangkat desa dalma membuat dan menyajikan laporan tahunan kegiatan desa. Kegiatan Pelatihan dilaksanakan sebanyak 5 (lima) kali pertemuan dengan jumlah peserta 5 (lima) orang perangkat desa. Peserta diberikan modul pelatihan sehingga membantu peserta dalam mengikuti pelatihan. Pelatihan ini dibantu oleh mahasiswa dalam mendampingi peserta selama pelatihan jika ada peserta yang mengalami kesulitan. Tim pengabdian pun menyediakan Icd sebagai media penunjang selama kegiatan pelatihan yang membantu peserta dalam mengikuti pelatihan aplikasi perkantoran.

Peserta sangat antusias dalam mengikuti pelatihan tersebut sehingga dapat meningkatkan wawasan dan pengetahuan perangkat desa dalam menggunakan aplikasi Microsoft Office. Hal ini dapat dilihat pada pertemuan terakhir, peserta langsung mengimplementasikan materi yang telah disampaikan untuk administrasi data desa.

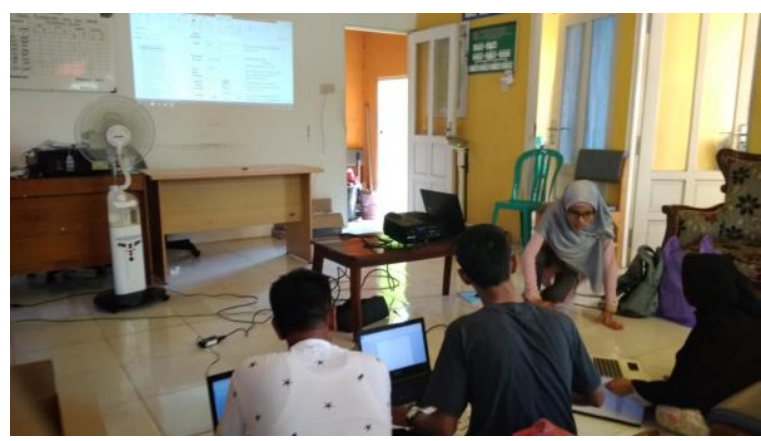

Gambar 1. Kegiatan pelatihan komputer perangkat desa Pemakuan.

Selain adanya peningkatan pemahaman terhadap aplikasi yang diajarkan. Peningkatan juga terjadi pada beberapa indikator kegiatan yang ditampilkan pada tabel 1. Beberapa pelayanan desa Pemakuan saat ini sudah mulai menggunakan komputer yang dioperasikan oleh admi desa, diantaranya adalah database desa dan persuratan. 
Pengetahuan perangkat desa terhadap website pedesaan juga meningkat. Hal ini diharapkan dapat meningkatkan laju pelayanan dan pembangunan desa Pemakuan. Peningkatan kemampuan komputer perangkat desa sangat penting. Beberapa kegiatan sejenis juga dilakukan oleh Sulistyanto (2017) yang melakukan kegiatan peningkatan kemampuan perangkat desa di Desa Gondangrejo, Karang anyar.

\begin{tabular}{clcc}
\multicolumn{4}{c}{ Tabel 1. Indikator kegiatan PKM } \\
\hline No & \multicolumn{1}{c}{$\begin{array}{c}\text { Komponen } \\
\text { Luaran }\end{array}$} & Sebelum & Sesudah \\
\hline 1 & $\begin{array}{l}\text { Pengetahuan } \\
\text { TIK }\end{array}$ & rendah & meningkat \\
2 & $\begin{array}{l}\text { Ketrampilan } \\
\text { komputer }\end{array}$ & rendah & meningkat \\
3 & $\begin{array}{l}\text { Layanan } \\
\text { berbasis TIK } \\
4\end{array}$ & terbatas & meningkat \\
& Web pedesaan & Tidak tau & memahami \\
\hline
\end{tabular}

Dari hasil pelaksanaan kegiatan
pengabdian yang telah dilakukan,
Peningkatan kemampuan komputer
perangkat desa Pemakuan dapat dikatakan
baik. Ada beberapa kendala yang dialami
selama kegiatan pengabdian diantaranya
(1) Keterbatasan laptop peserta dalam mengikuti pelatihan dan Icd sebagai alat penunjang (2) alokasi waktu yang terbatas karena beberapa kegiatan yang dimiliki oleh peserta

Thoha (2007) mengungkapkan bahwa kemampuan adalah bagian kematangan dan pengetahuan seseorang yang diperoleh dari pendidikan, pelatihan dan pengalaman. Kemampuan berhubungan erat dengan fisik dan mental dalam melaksanakan pekerjaan, sehingga sering disebut sebagai kemampuan kerja.

\section{Penutup}

Berdasarkan hasil kegiatan PKM yang telah dilaksanakan terdapat peningkatan pemahaman dan praktek ketrampilan komputer dan internet sebesar 75\%. Pengelolaan data base yang sebelumnya belum dilakukan, saat ini mulai dilakukan. Perangkat desa juga telah memahami beberapa website diskusi pedesaan. Namun masih diperlukan dorongan dan pendampingan untuk lebih trampil dalam penggunaan aplikasi ms. Word dan Excel.

\section{UCAPAN TERIMA KASIH}

Ucapan terima kasih disampaikan
kepada Lembaga Penelitian dan
Pengabdian kepada Masyarakat
Universitas Lambung Mangkurat (LPPM
ULM) melalui $\quad$ SIMLITABMAS
KEMENRISTEKDIKTI yang telah mendanai
kegiatan ini melalui program kemitraan
masyarakat pendanaan Tahun 2019.

\section{DAftar Pustaka}

Anonymous. 2014. Undang-undang Republik Indonesia Nomor 6 Tahun 2014 tentang Desa. Sekretariat Negara. Jakarta.

Moeljanto, T. 2008. Pembangunan, Dilema dan Tantangan. Yogyakarta: Pustaka Pelajar.

Suprapto E, Murtafiah w, Apriandi d, Setyansah RK.. 2016. Pelatihan pengelolaan database desa untuk meningkatkan Kinerja perangkat desa kranggan kecamatan geger 
Kabupaten madiun. Jurnal terapan abdimas. 1(1): 32-34.

Sulistyanto h. 2017. Pakom pelatihan pengoperasian komputer bagi perangkat Desa di kecamatan Gondangrejo kabupaten Karanganyar. Warta LPM. 20(2): 111114.

Thoha M. 1998. Perspektif Perilaku Birokrasi, Jakarta (ID): Rajawali Press.

\section{Riwayat Hidup PenUlis}

\section{Dwi Kartini, M.Kom}

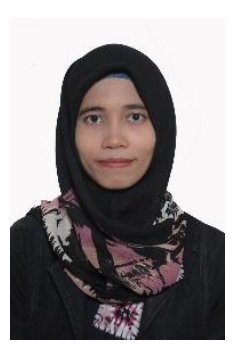

Lahir di Jakarta, 21 April 1987. Staf pengajar di PS Ilmu Komputer, FMIPA Universitas Lambung Mangkurat. Studi S1 Sistem Informasi di Universitas Putra Indonesia "YPTK" Padang lulus tahun 2010; S2 Magister IImu Komputer di Universitas Putra Indonesia "YPTK" Padang lulus tahun 2011. 